\title{
Pre-Senile Dementia
}

National Cancer Institute

\section{Source}

National Cancer Institute. Pre-Senile Dementia. NCI Thesaurus. Code C34523.

The presence of dementia in an individual younger than age sixty five. 